Disscussion. Since the number of repeat CS tends to increase, many authors have started to study the influence of repeated CS on adhesion formation. Our study showed that a cesarean section does not pass without a trace for patients. Adhesions with the expression of varying degrees of severity is noted in almost all women with a history of abdominal delivery. Dense adhesions between the uterus and anterior abdominal wall and bladder were observed in most women who underwent repeat CS. We also found adhesions of different localization. Nowdays there isn't any standart classification of adhesion after CS, the need for a standardized adhesion classification is obvious. Routine use of a standardized adhesion classification might enable future investigators to conduct more reproducible retrospective studies and the most important thing is that knowledge of the presence and severity of adhesions will prepare the obstetrician for future repeat cesarean deliveries. The presence of adhesions increases time to delivery of the fetus and time of surgery. It should be noted that presence of adhesions can increase maternal morbidities with each subsequent cesarean delivery. Such as bowel and bladder injury, need for hysterectomy, post-partum bleeding and etc. We propose to use 3 different classification of intraabdominal adhesions after cesarean delivery to have more exact image of adhesions condition in pelvic and abdomen. Because each classification hasit own advantages and disadvantages, some of them describe in details localization, the other one describe the intensity and extent of adhesions. For this reason only a combination of these classifications can provide a complete picture of the adhesions.

***

1. Hamilton BE, Ventura SJ, Osterman MJK, Kirmeyer S, Mathews TJ, WilsonE(2011)Births:finaldatafor2009.NatVitalStatRep60:1-35

2. Martin JA, Hamilton BE, Ventura SJ et al. Births: Final data for 2003. National vital statistics reports; vol 54 no 2. Hyattsville, MD. National Center for Health Statistics. 2005. http://www.cdc.gov/ nchs/births.htm

3. Barber EL, Lundsberg LS, Belanger K, Pettker CM, Funai EF, Illuzzi JL (2011) Indications contributing to the increasing cesarean delivery rate. Obstet Gynecol 118:29-38

4. MacDorman MF, Menacker F, Declercq E: Cesarean birth in the United States: epidemiology, trends, and outcomes. Clin Perinatol, 2008; 35(2): 293-307

5. Morales KJ, Gordon MC, Bates GW Jr (2007) Postcesarean delivery adhesions associated with delayed delivery of infant. Am J Obstet Gynecol 196:461.e1-461.e6

6. Tulandi T, Agdi M, Zarei A, Miner L, Sikirica V (2009) Adhesion formation and morbidity after repeat cesarean delivery. Am J Obstet Gynecol 201:56.e.1-56.e.6

7. Diamond MP (2011) Postoperative adhesions: an underappreciated complication of cesarean deliveries. Am J Obstet Gynecol 205(6 Suppl):S 1

\title{
Badalova A.O. \\ The role of hyperurbanization processes in the formation of emotional stress among adults
}

Azerbaijan Medical University

(Azerbaijan, Baku)

doi: 10.18411/scienceconf-09-2019-21

idsp: scienceconf-09-2019-21

\section{Abstract}

The work was carried out at the bases of 3 polyclinics in Baku (patients), 3 schools and 4 kindergartens (parents), 12 shopping facilities and offices (employees). We used Reeder and SF36 questionnaires adapted to local conditions. 1787 analyzed questionnaires and medical charts in hospitals. A fixed group of 857 residents was observed for 4-7 months. Weak ES level was detected in $29.3 \pm 1.1 \%$ of the population, average LEVEL in $51.3 \pm 1.2 \%(\mathrm{P}<0.001)$, strong level in $19.4 \pm 0.9 \%(\mathrm{P}<0.001)$. Identified 16 " family "and 12 " service " stressors, which play a major role in the formation of ES. With a strong level of ES simultaneously on the body affect an average of $5.47 \pm 0.32$ and $5.12 \pm 0.31$ units of noted stressors. The effectiveness of training residents coping ES measures and their implementation for $4-7$ months is $45.9 \pm 2.1 \%$. 
Organizational and information work among doctors on appropriate assistance to the population regarding ES and the dissemination and training of urban residents coping measures ES allows to eliminate the impact on the body of stressors.

Keywords: hyperurbanization, urban residents, emotional stress, stressors, coping

\section{Аннотация}

Работу провели на базах 3 поликлиник г. Баку (пациенты), 3 школах и 4 детских садах (родители), 12 торговых объектах и офисах (работники). Использовали опросники Reeder и SF-36, адаптированных к местным условиям. Анализировали 1787 анкет и амбулаторные карты в поликлиниках. Фиксированную группу из 857 жителей наблюдали в течение 4-7 месяцев. Слабый уровень ЭС выявлен у $29,3 \pm 1,1 \%$ жителей, средний

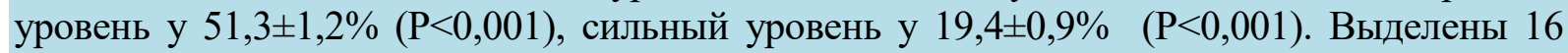
«семейных» и 12 «служебных» стрессоров, играющих основную роль в формировании ЭС. При сильном уровне ЭС одновременно на организм воздействуют в среднем $5,47 \pm 0,32$ и $5,12 \pm 0,31$ единиц отмеченных стрессоров. Эффективность обучения жителей

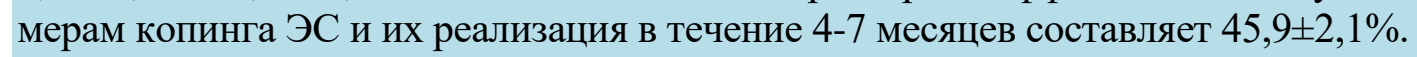

Организационно-информационная работа среди врачей по соответствующей помощи населению относительно ЭС и распространению и обучению городских жителей мерам копинга ЭС позволяет устранять воздействие на организм стрессоров.

Ключевые слова: гиперурбанизация, городские жители, эмоциональный стресс, стрессоры, копинг.

In recent years, population-based studies on emotional stress (ES) among the population have been intensified, showing their ubiquitous prevalence and aggravating impact on the health, working capacity and quality of life of the population, up to $70 \%$ of various diseases are formed under the influence of ES $[1,2,3,4]$. Stress is an independent risk factor for most psychosomatic diseases $[5,6]$.

Purpose. Study of the influence of hyperurbanization processes on the formation of the causes contributing to the prevalence of ES among urban residents and their assessment.

Material and methods. The work carried out on the bases 3 urban clinics (Nasimi, Yasamal and Sabunchi districts), with outreach to their patients and parents at neighboring institutions (3 schools, 4 kindergartens and nurseries) and workers on 12 commercial facilities, offices. Based on the international standardized questionnaire SF-36 developed a locally adapted questionnaire (in Azerbaijani and Russian), which included blocks of questions reflecting the social and hygienic aspects of ES. Each questionnaire was accompanied by a Reader questionnaire (scale) [12] to diagnose and determine the level of ES. In total, 4000 questionnaires were prepared and distributed in these objects, collectives of these objects participated in the distribution and collection of questionnaires, as well as students of 3 and 4 courses of AMU. The response was 1787 questionnaires $(44.7 \pm 0.8 \%)$. Questions of questionnaires were coded that facilitated and accelerated their processing.

Research results and their discussion. According to the Reader's scale, a weak level of ES (up to 1.09 points) is a positive (protective) reaction of the body to the effects of various stressors. Partly the same property has the average level of ES (1.09-2.08 points), but with frequent and prolonged exposure to stressors, it has a negative, painful effect on the body. Almost always a similar effect on the body has a strong level of ES (more than 2.08 points). According to the survey results, 523 of 1787 respondents had a weak ES level, so this group can be used as a control $(29.3 \pm 1.1 \%), 917$ respectively average $(51.3 \pm 1.2 \%$; $\mathrm{t}=13.49 ; \mathrm{P}<0.001), 347$ strong $(19.4 \pm 0.9 \% ; \mathrm{t}=20.09 ; \mathrm{P}<0.001)$. Urban residents are affected by a large number of stressors, but they are mainly due to two spheres of human activity-family and service. The family is the basic socio-economic and demographic unit of any society. Creating a family, ensuring its development and well-being and reproduction of healthy offspring requires great efforts of the couple. Throughout the long period of functioning of the family solves many 
problems both positive and negative, the solution of which is associated with the impact on the body of various stressors. All surveyed as unfavorable family stressors were noted problems related to health, upbringing and education of children, ensuring the welfare of the family, unsettled housing, the high cost of food and their preparation, material dependence, preparation and observance of the family budget, lack of free time. The frequency of these family stressors varies from $26.8 \pm 1.0$ to $28.4 \pm 1.1 \%(\mathrm{t}=1.07 ; \mathrm{P}>0.05)$. Significantly less frequency of another group of stressors $(\mathrm{t}=5.85 ; \mathrm{P}>0.05)$, which are represented by strained relationships in the family, dissatisfaction with housing conditions, large family size, housekeeping, parental care, utility costs, overcrowding - from $17.4 \pm 0.9$ to $18.9 \pm 0.9 \%(\mathrm{t}=1.18 ; \mathrm{P}>0.05)$. The frequency of other family stressors was the lowest and amounted to $8.5 \pm 0.7 \%(\mathrm{t}=7.81 ; \mathrm{P}<0.001)$. Noted family stressors are inherent in almost all respondents, but depending on the level of ES their frequency differs significantly. According to the reliable value of the van der Waerden test $(X=6.83$; $\mathrm{P}<0.01$ ), frequency of a number of indicators of stressors a strong level of ES is higher than the frequency of the same fold of the average level of ES, and the frequency of this range is above the frequency range with low ES. Therefore, for each surveyed with a strong level of ES in the average $5.47 \pm 0.32$ family stressors, their number is less among those surveyed with an average level of $\mathrm{ES}-3.61 \pm 0.21$ stressors $(\mathrm{t}=4.89 ; \mathrm{P}<0.001)$ and especially among those surveyed with a weak level of ES $-2.08 \pm 0.24$ stressors $(\mathrm{t}=3.92 ; \mathrm{P}<0.001)$. Most of these stressors are manageable and if measures are taken to reduce their simultaneous exposure to 2 stressors, it is possible to achieve a limitation of the prevalence among urban residents of ES with medium and strong levels. The well-being of the family depends largely on material prosperity. In today's socioeconomic environment, the work of all adult family members is necessary to achieve the necessary material means, especially in cities where life is much more expensive. Therefore, 1350 of 1787 respondents worked (served) in different industries-from service personnel to businessmen and high-ranking officials (75.5 $\pm 1.0 \%)$. 176 respondents were temporarily unemployed $(9.6 \pm 0.7 \%), 261$ out of 921 interviewed women did not work and were engaged only in household and child-rearing, i.e. they were Housewives $(28.3 \pm 1.5 \%)$. The marked service stressors are characteristic for all groups of the surveyed. However, the frequency of each of them is less among respondents with a weak level of ES than the frequency of similar stressors with an average level of ES and especially among respondents with a strong level of ES. The difference in the series of stressor frequencies is confirmed by a reliable value of the van der Waerden criterion $(\mathrm{X}=8.14 ; \mathrm{P}<0.01)$. There are 2 groups of stressors that differ in the level of detectability, which is especially clearly seen from the generalized data. The detection rate of the second group of stressors is much lower $(\mathrm{t}=6.64 ; \mathrm{P}<0.001)$, which represented no career growth, working hours, the remoteness of the job, finding a new job, unemployment and other stressors, their frequency varies from $18.0 \pm 0.9$ and $21.4 \pm 1,0 \%(\mathrm{t}=2,52 ; \mathrm{P}<0.05)$. Much lower frequency of detection of the second group of stressors $(\mathrm{t}=6,64 ; \mathrm{P}<0.001)$, which represented no career growth, working hours, the remoteness of the job, finding a new job, unemployment and other stressors, their frequency varies from $18.0 \pm 0.9$ and $21.4 \pm 1,0 \%(\mathrm{t}=2,52 ; \mathrm{P}<0.05)$. Both family stressors and service stressors are controlled and by correcting stress-overcoming behavior (coping) it was possible to reduce the level of ES. For example, with a weak level of ES, which is recognized as a normal, positive phenomenon, the body of the respondents is simultaneously affected by an average of $1.66 \pm 0.23$ stressors. At the average level of ES, their number increases to $3.12 \pm 0.21$ stressors $(\mathrm{t}=4.71 ; \mathrm{P}<0.001)$, and at a strong level of $\mathrm{ES}$, respectively, to $5.12 \pm 0.31$ stressors $(\mathrm{t}=5.41 ; \mathrm{P}<0.001)$. Coping makes it quite steadily to eliminate controllable stressors. However, the medical awareness of respondents regarding ES and especially its coping is very low. It is no coincidence that if their medical treatment for morbidity is on average $4.02 \pm 0.15$ visits to the clinic during the year, then for ES it is only $0.75 \pm 0.11$ visits. The situation with medical awareness of the respondents is very unfavorable, but it varies depending on the level of ES. For example, full awareness in respondents with low ES level was $18.5 \pm 1.7 \%$, in respondents with average level it was even less-10.7 $\pm 1.0 \%(\mathrm{t}=3.96 ; \mathrm{P}<0.001)$, and in the respondents with a strong level of ES it did not exceed $4.3 \pm 1.1 \%(\mathrm{t}=4.30 ; \mathrm{P}<0.001)$. At the same 
time,poor awareness among the former was much less $-13.8 \pm 1.5 \%$ than among the latter $32.2 \pm 1.5 \%(\mathrm{t}=8.68 ; \mathrm{P}<0.001)$ and even more so among the third $-50.1 \pm 2.7 \%(\mathrm{t}=5.79 ; \mathrm{P}<0.001)$.

$$
* * *
$$

1. Щербатых Ю.В. Психология стресса и методы коррекции. СПб : Питер 2008.

2. Codena J., Vinaccia S., Perez A. et al. The impact of disease activity on the quality of life, mental health status and family dysfunction in Colombian patients with rheumatoid arthritis.// J Clin Rheumatol 2008. 9: 3: 142-150.

3. Collins R.E., Lopez L.M., Marteau N.V. Emotional impact of screening: A systematic review and metaanalysis. // BMC Public Health 2011; 11: 603.

4. Новикова И.А., Сидоров П.И., Соловьев А.Г. Основные факторы риска развития психосоматических заболеваний. //Терапевтический архив, №1, 2007, ст.61-64.

5. $\quad$ Metcalfe C., Dovey Smith G., Sterne J.A., Heslop P., Macleod J., Hart C.L.(K) Cause-specific hospital admission and mortality among working men: Association with socioeconomic circumstances in childhood and adult life and the mediating role of daily stress.// Eur J Public Health 2009; 15:3: 238-244.

6. Reeder L., Champan J., Coulson A. Socioenvironmental stress, tranquilizers and cardiovascular disease//Proceedings of the Excerpta Medica International Congress Series. - 1968, 182, p.226-238.

\title{
Gasanova V.L. \\ Clinicoepidemiological analysis and immunological characteristics of allergic dermatitis with concomitant intestinal parasites
}

\author{
Azerbaijan Medical University \\ (Azerbaijan, Baku)
}

doi: 10.18411/scienceconf-09-2019-22

idsp: scienceconf-09-2019-22

\section{Аннотация}

Обследованы 510 больных с аллергодерматозами с сопутствующими паразитозами. Из них 139 больных с аскаридозам, 120 больных с энтеробиозом, 47 больных с стронгилоидозом, 77 с трихоцефалезом, 127 больных с лямблиозом. Проводились статистические, клинические, паразитологические и эпидемиологические методы исследование. Распределение больных аллергодерматозами с сопутствующими кишечными паразитозами по возрастным группам показало, что меньше всех больные были в возрасте $1-3$ года $(3,92 \pm 0,86 \%)$ и 51 и выше лет $(6,28 \pm 1,07 \%)$, несколько больных и почти одинаково больных были в возрасте $12-17$ лет $(13,33 \pm 1,51 \%)$, в возрасте $18-30$ лет $(14,51 \pm 1,56 \%)$ и в возрасте $31-50$ лет $(13,14 \pm 1,50 \%)$. Больше всех больные составляли в возрасте 8-11 лет $(25,10 \pm 1,92 \%)$ и в возрасте 4 -7 лет $(23,73 \pm 1,88 \%)$

Распределение больных аллергодерматозов с сопутствующими аскаридозом, энтеробиозом, трихоцефалезом, лямблиозом было также как у больных с общими паразитозами, кроме стронгилоидоза. Аллергодерматозы с сопутствующими кишечными паразитозами среди населения Азербайджана и в настоящее время встречаются очень часто. Эти больные встречаются во всех возрастных группах. Частота встречаемости аллергодерматозов с сопутствующими паразитозами среди женщин и мужчин, а также по месту жительства отмечается по нозологии кишечных паразитов.

Ключевые слова: дети, взрослые, аллергодерматозы, паразитозы

Among the many etiological factors parasitological diseases occupy a special place.[1] Pathogens of some parasitic diseases penetrate the skin into the body, some live in the skin and subcutaneous tissue, and intestinal parasites with their metabolic substance affect the morphological and functional activity of the skin.[2]

Allergodermatoses are one of the most common skin pathologies among the populations of many countries of the world [3], including Azerbaijan. 